\title{
Student Library Committees
}

\begin{abstract}
Although at times in the past, college student library committees have been fairly common, they have in recent years become less so. Some institutions that formerly had such committees report having discontinued them because their functions were being more easily accomplished in other ways. Some of these functions-and possible substitutions for them-are outlined. Local circumstances should determine the use or nonuse of student library committees.
\end{abstract}

HE COLLEGE LIBRARY must be aware of students as people; it must be student conscious. A vital part of this awareness of students as individuals is the necessity for the library staff to encourage students to use the library in every way possible. According to Guy Lyle this encouragement to use the library can be made at the service desks, through instruction in the use of the library, through printed and nonprint media, and-in earlier editions of his excellent textbook-through the student library committee. ${ }^{1}$ Much has already been written about the first three relationships with the students, but very little has been written about the fourth. This has probably been due to the fact that so few colleges have experimented with student library committees.

Ideally the student library committee should assist the library staff in interpreting the role of the library in the academic life of the student. It should aid the library staff in reaching students with the tremendous amount and variety of material available for their use. Libraries offer many services of which the stu-

${ }^{1}$ Lyle, Guy R., The Administration of the College Library (2nd ed. rev., New York: N. W. Wilson \& Co., 1949), p. 493.

Mr. Cain is Librarian of Wisconsin State College at Whitewater. dent body is unaware. The student library committee could be the impetus for increased publicity in college publications concerning the wealth of material for instructional and leisure time reading and also the variety of services which are available to students.

The student library committee could serve as a sounding board for student suggestions as to desired reading materials and additional or revised services. It could assist the librarian in soliciting small gifts of money to be used for books, periodicals, or equipment. The student library committee could be most helpful in supporting the librarian when disciplinary problems arise, and it could instill a spirit of loyalty to the library staff in its efforts to give as good service as possible to every library patron.

There are other functions that worthwhile student library committees have performed. Students that are appointed to such a committee should have ability in student leadership, ability to carry responsibility, and an interest in reading good literature. At Greenville College the student council selects the student library committee members in consultation with the librarian. ${ }^{2}$ This is good because it gives the librarian a chance to help select the desirable students and

\footnotetext{
2Dare, R. E. "Student Advisory Committee for the College Library," Library Journal, LXIV (December 1,1939$), 930-32$.
} 
discourage the appointment of those students who want to run the library rather than become acquainted with the problems of the library.

The student library committee, of course, is not worthwhile when there is no interest shown by its members; when it fails to support the librarian or his program; when the members fail to attend the meetings regularly; when the members look at the library from a narrow point of view; when the members fail to take the time to acquaint themselves fully with the library problems brought up for discussion; and when they fail to observe library rules and regulations and expect special favors and privileges from the librarian and library staff.

Mr. Lyle in the second edition of his Administration of the College Library listed the following colleges as having successful student library committees in the late 1940's: Greenville, Mills, Penn State, Rockford, Scripps, and Wellesley. Only two of these colleges, however, have student library committees today. The rest report that they have done away with their committees because (1) there was not enough real business for it to attend to; (2) members of the committee were too busy with other things; (3) small student body did not warrant having such a committee; (4) student assistant staff more or less assumed the responsibilities of the now defunct student library committee; and (5) some of the members of the student library committee wanted to run the library. ${ }^{3}$

The two colleges that report still having student library committees say they are aiding the library staff in the following ways: (1) the committee gives the student point of view on the library to the librarian; (2) they aid in the selection of recreational books; (3) they sponsor an elaborate celebration of $\mathrm{Na}$ tional Library Week and one or two book chapels during the year; (4) they

\footnotetext{
In correspondence with the author.
}

advise the librarian on library rules, regulations, and library hours; (5) they assist in having more library publicity printed in the college newspaper.

On the whole college librarians are very conscious of student opinion and are trying to give the students as good library service as is possible. Instead of having student library committees which take much time, they have been successful in determining student needs through the following: (1) informal conferences with individual students; (2) receiving suggestions from students by having a suggestion box near the circulation desk; (3) informal conferences with professors about problems of their students; (4) receiving suggestions from student assistants; (5) receiving suggestions from students called in before regular faculty library committees on library problems; (6) receiving suggestions from students, who serve as members of faculty committees that the librarian serves on; and (7) discussing library problems two or three times annually with officers of different student groups and giving the students a chance to ask questions and say anything they want concerning the library and the student body.

Most librarians apparently have concluded that the student library committee system is not successful. The students are so busy with their studies and are so busy participating in extracurricular activities that they do not have time to carry out their functions as members of the committee. Most libraries can keep in touch with the student body and keep the student body informed of library problems by calling in the presidents of the fraternities, sororities and independent groups as the situation demands it, since these organizations often represent the thinking and feeling of the student body.

The local situation on a college campus therefore determines whether a student library committee will be worth- 
ably use the new rules in establishing new headings and will accept LC cards, which will follow the new rules when new headings need to be established but will not change established entries.

John H. Moriarty (Purdue University) presented an interim report of three pages of text and twenty-eight charts on "Growth In ARL Libraries, 1950-1980." From the figures reported by fifty-eight libraries (not including LC) eight "composite" libraries were represented, and volumes held, volumes acquired, and total library expenditures were shown and projected to 1980 . The average "composite," for example, held just under 900,000 volumes in 1950-51, while in 1963-64 this figure had risen to $1,490,000$ volumes, indicating that the fiftyeight libraries held a total of 86.4 million volumes. The projected size of the average collection in 1980 would be $2,860,000$ volumes, but Mr. Moriarty said that a more realistic figure would be $3,750,000$ volumes. A full report is expected late in the summer and will be mailed to ARL members.

John Lorenz (director of the Division of Library Services and Educational Facilities, HEW) described the reorganization of the Office of Education, especially as it affects library services, into four bureaus corresponding to levels of education: elementary and secondary education; higher education; adult and vocational education, including educational TV and the former Library Services Branch; and a bureau of research. In addition, a national center for educational statistics was created.

William N. Locke (Massachusetts Institute of Technology) reported on Project Intrex and a five-week planning conference; Mr. Logsdon described the status of the Medical Library Assistance Act of 1965; Stephen McCarthy discussed the problem of overhead on government research projects and how libraries could get a fair percentage; and a number of committee chairmen or their representatives filed reports ranging in coverage from the Farmington Plan to the National Union Catalog of Manuscript Collections.

The Executive Secretary, James E. Skipper, reported, among other things, on the Systems Development Corporation's study for COSATI of the structuring of a national library information system, on legislation, and on the fact that he will represent ARL at the Helsinki meeting of IFLA. The chair- man reported that the Board of Directors had approved a special fund, not to exceed $\$ 1,000$, for use of the ALA Washington Office on matters of mutual interest to ARL and ALA. At the Executive Secretary's request, a visiting committee to survey the secretariat has been authorized. The Board also voted ARL's thanks to Professor Julian Levi (University of Chicago) for his assistance to the association; it approved the exchange of information when the ARL and the Association of College and Research Libraries have counterpart committees; and it recommended a change in the by-laws to establish the officers of ARL as an executive committee empowered to act between meetings of the Board and the membership, authority that is especially important when legislative developments require prompt action.

After a vote of thanks to Wayne State University for the excellent arrangements for the conference, the sixty-sixth meeting adjourned. ARL will meet next in Chicago, immediately preceding the ALA Midwinter conference.-Elizabeth E. Hamer.

\section{STUDENT LIBRARY COMMITTEES}

(Continued from page 494)

while or not. The librarian and the student members of the committee are the deciding factors in this situation. A student library committee can be very successful and helpful to the librarian and the library staff one year and fail the following year. If there is no continuity of members on the committee, it can turn out to be an abysmal failure. It appears, however, that the trend over a long period of time has been to find out student opinion and work with students in ways other than through a student library committee.

\footnotetext{
IN THE WINTER OF 1965 a Student Library Committee was established at Oakland University, Rochester, Mich. This committee would like to know of similar groups in the United States and effect they have in gearing university libraries to the needs of students and faculty. Responses should be sent to George M. Bailey, executive secretary, ACRL, 50 E. Huron St., Chicago.
} 